Lepr Rev (1992) 63, 329-336

\title{
Persistence of Mycobacterium leprae in the peripheral nerve as compared to the skin of multidrug-treated leprosy patients
}

\author{
V P SHETTY, K SUCHITRA, M W UPLEKAR \& \\ $\mathrm{N}$ H ANTIA* \\ The Foundation for Medical Research, 84, A.R.G. Thadani Marg, \\ Worli, Bombay 400018, India
}

Accepted for publication 5 June 1992

\begin{abstract}
Summary Skin and nerve biopsies obtained from 18 multibacillary (MB) and 16 paucibacillary (PB) cases of leprosy who had been fully treated by the WHO regimen were assessed for bacterial load using different staining techniques. In addition skin and nerve homogenates of $10 \mathrm{MB}$ cases were tested for 'persistor' Mycobacterium leprae using immunosuppressed mice.

While significant amounts of integral bacilli and BCG cross-reactive antigen of $M$. leprae were detected both in skin and nerve tissues of all the MB cases $(100 \%), 56 \%$ of skin and $62 \%$ of nerve biopsies of PB cases also showed the presence of BCG cross-reactive antigen.

Detection of 'persistor' $M$. leprae in $2 / 10$ skin biopsies $(20 \%)$ and $3 / 10$ nerve biopsies $(30 \%)$ of MB cases was thought to be unexpectedly high after 2 years of MDT.
\end{abstract}

\section{Introduction}

Although the peripheral nerves, and the Schwann cells in particular, are well recognized to be the seat of disease in leprosy, ${ }^{1}$ decisions regarding diagnosis and therapy are based largely on skin manifestations and the presence or absence of bacilli within the skin lesions. This is chiefly because of the ease of investigation and also because skin lesions do provide a good indication of the activity of the disease process. However, it has been demonstrated in histopathological studies that in the same patient, nerves generally show lesions which are more advanced and also harbour bacilli exhibiting solid forms which indicate a higher degree of viability. ${ }^{2,3}$ This is believed to be because nerves, being immunologically protected, are favoured sites for bacillary survival and multiplication, ${ }^{4,5}$ It is possible that after prolonged chemotherapy, while skin lesions may not have viable bacilli, some viable bacilli may persist within the nerves and may cause a relapse at a later stage af ter therapy has stopped. THELEP trials with MDT at Bamako and Chingleput showed the presence of persistor M. leprae in $9 \%$ of cases. ${ }^{6}$

* Corresponding author. 
The present study was undertaken in order to determine and compare the bacterial load as well as the viability within the peripheral nerves and the skin of leprosy patients who had been treated with the WHO recommended multidrug therapy.

\section{Patients and method}

A total of 18 multibacillary cases (BL-LL) treated for a minimum of 2 years and 16 paucibacillary cases $(\mathrm{BT}-\mathrm{TT})^{7}$ treated for a minimum of 6 months with the WHO recommended multidrug regime ${ }^{8}$ were studied for bacterial load in the skin and nerve using different staining techniques. Additionally skin and nerve biopsies from 10 of the multibacillary cases were studied for bacterial viability using the mouse footpad technique.

Where possible, skin biopsies of all the cases were taken from lesions that appeared most active, but in the absence of any active lesions, the choice of biopsy in lepromatous patients was either earlobe. In tuberculoid patients with healed lesions, the biopsy was taken from a clinically inactive lesion. The selection of the peripheral nerve for biopsy was based on the amount of clinical and electrophysiological involvement. An involved sural nerve was biopsied in all except 1 of the lepromatous patients, the biopsy in the tuberculoid patients varied according to the site of involvement and included the sural (6),

Table 1. Bacterial load in skin and nerve of treated MB cases using different staining techniques

\begin{tabular}{|c|c|c|c|c|c|c|c|}
\hline \multirow[b]{2}{*}{ No. } & \multicolumn{4}{|c|}{ Skin } & \multicolumn{3}{|c|}{ Nerve } \\
\hline & $\begin{array}{c}\mathrm{Rx} \\
\text { doses } \\
\text { MDT-MB }\end{array}$ & $\begin{array}{c}\text { Smear BI } \\
(\text { Avg) } \\
(+)\end{array}$ & $\begin{array}{l}\text { Histo BI } \\
(+)\end{array}$ & $\begin{array}{c}\text { Anti BCG. } \\
(+)\end{array}$ & $\begin{array}{l}\text { Histo BI } \\
(+)\end{array}$ & $\begin{array}{c}\text { Anti BCG. } \\
(+)\end{array}$ & $\begin{array}{c}\text { EM BI } \\
(+)\end{array}$ \\
\hline 1 & 32 & $3 \cdot 3$ & 3 & 3 & 3 & 3 & 4 \\
\hline 2 & 24 & $0 \cdot 2$ & 0 & 1 & 0 & 2 & 2 \\
\hline 3 & 24 & 0 & 0 & 2 & 0 & 1 & 2 \\
\hline 4 & 30 & $4 \cdot 2$ & 2 & 2 & 3 & ND & ND \\
\hline 5 & 24 & 0 & 2 & 1 & 2 & 1 & 2 \\
\hline 6 & 24 & 0.5 & 3 & 2 & 3 & 2 & 3 \\
\hline 7 & 24 & $0 \cdot 3$ & 2 & 1 & 0 & 2 & 2 \\
\hline 8 & 24 & $2 \cdot 0$ & 2 & 3 & 2 & 2 & 2 \\
\hline 9 & 24 & $4 \cdot 3$ & 3 & 2 & 3 & 2 & 3 \\
\hline 10 & 24 & $2 \cdot 1$ & 3 & 3 & 3 & 3 & 3 \\
\hline 11 & 24 & $1 \cdot 0$ & 3 & 3 & ND & ND & 2 \\
\hline 12 & 24 & 0 & 0 & 1 & 0 & 2 & 2 \\
\hline 13 & 24 & $0 \cdot 3$ & 0 & 0 & 0 & 2 & 2 \\
\hline 14 & 24 & $2 \cdot 1$ & 3 & 3 & 2 & 3 & 3 \\
\hline 15 & 24 & $0 \cdot 2$ & 2 & 2 & 0 & 2 & 2 \\
\hline 16 & 24 & 0 & 2 & 2 & 0 & 3 & 3 \\
\hline 17 & 24 & 0 & 2 & 1 & 0 & 2 & 2 \\
\hline 18 & 24 & 0 & 2 & 2 & 2 & 2 & 2 \\
\hline \multicolumn{2}{|c|}{ + VE staining } & $12 / 18$ & $14 / 18$ & $17 / 18$ & $9 / 17$ & $16 / 16$ & $17 / 17$ \\
\hline
\end{tabular}
$4+$.

ND, not done; semiquantative grades: $\mathrm{BI}=0$ to $6+($ Ridley DS 1964, 1985); AntiBCG $=0$ to 
the cutaneous branch of the radial (7), the cutaneous branch of the ulnar (1), the lateral thoracic (1) and the superficial peroneal (1).

\section{Determination of the bacterial load}

The following methods were employed for the determination of the bacterial load:

a Multiple slit-skin smears were obtained from all the patients before biopsy. Smears stained with Fite-Farraco were scored for their bacterial index (BI) using Ridley's scale. ${ }^{9}$

b Paraffin sections of skin and nerve biopsies were stained with Trichrome modified FiteFarraco (TRIFF) and the bacterial index was determined on tissue sections using Ridley's method. ${ }^{10}$

c Paraffin sections of skin and nerve tissues were also stained with anti-BCG antibody (from DAKO) for cross-reactive Mycobacterial antigen using the peroxidaseantiperoxidase (PAP) technique.

d Araldite embedded ultrathin transverse sections of the nerve were scanned for the presence of osmiophilic bacilli using electron microscopy (EM). We determined the bacterial index (BI) at EM level for a given cross-section on the following grounds.

$1+=1$ or 2 cells carrying few bacilli $(<10)$;

$2+=$ few cells carrying single to small clusters of bacilli $(>10$ to $<100$ );

$3+=$ several cells carrying clusters of bacilli $(>100)$, and so on.

All these are well standardized, routinely used techniques in our laboratory.

Table 2. Bacterial load in skin and nerve of treated PB cases using different staining techniques

\begin{tabular}{|c|c|c|c|c|c|c|c|}
\hline \multirow[b]{2}{*}{ no. } & \multicolumn{4}{|c|}{ Skin } & \multicolumn{3}{|c|}{ Nerve } \\
\hline & $\begin{array}{c}\mathrm{KX} \\
\text { doses } \\
\text { MDT-PB }\end{array}$ & $\begin{array}{c}\text { Smear BI } \\
(+)\end{array}$ & $\begin{array}{l}\text { Histo BI } \\
(+)\end{array}$ & $\begin{array}{c}\text { Anti BCG. } \\
(+)\end{array}$ & $\begin{array}{l}\text { Histo BI } \\
(+)\end{array}$ & $\begin{array}{c}\text { Anti BCG. } \\
(+)\end{array}$ & $\begin{array}{c}\text { EM BI } \\
(+)\end{array}$ \\
\hline 1 & 12 & & 0 & 1 & 0 & + & 0 \\
\hline 2 & 12 & & 0 & 1 & 0 & + & 0 \\
\hline 3 & 7 & & 0 & 0 & 0 & 1 & 0 \\
\hline 4 & 10 & & 0 & 2 & 0 & 1 & 0 \\
\hline 5 & 12 & & 0 & 0 & 0 & + & 0 \\
\hline 6 & 6 & & 0 & 1 & 0 & 1 & 0 \\
\hline 7 & 12 & & 0 & 1 & 0 & 1 & 2 \\
\hline 8 & 10 & $-v e$ & 0 & + & 0 & 1 & 0 \\
\hline 9 & 18 & & 0 & 1 & 0 & 0 & 0 \\
\hline 10 & 6 & & 0 & 0 & 0 & 2 & 1 \\
\hline 11 & 7 & & 1 & 1 & 1 & 2 & 2 \\
\hline 12 & 6 & & 0 & 0 & 0 & 1 & 0 \\
\hline 13 & 9 & & 2 & 1 & 2 & 1 & 2 \\
\hline 14 & 6 & & 0 & 1 & 0 & 0 & 0 \\
\hline 15 & 6 & & 0 & 0 & 0 & 3 & 2 \\
\hline 16 & .6 & & 0 & 0 & 0 & + & 0 \\
\hline \multicolumn{2}{|c|}{ + VE staining } & 0 & $2 / 16$ & $9 / 16$ & $2 / 16$ & $10 / 16$ & $5 / 16$ \\
\hline
\end{tabular}

+ , Doubtful. 


\section{Determination of bacterial viability}

Skin and nerve homogenates from 10 of the above-treated multibacillary cases only, were studied for bacterial viability. Skin and nerve homogenates were prepared immediately after biopsy using sterile measures. The bacterial load per gram weight of skin and nerve tissues was determined using WHO guidelines and $0.03 \mathrm{ml}$ of the homogenate containing not more than $10^{5}$ bacteria were injected into both hind footpads of Swiss white mice thymectomized and irradiated with 5 graded doses of $200 \mathrm{rad}$ each of ' $\mathrm{X}$ ' irradiation at biweekly intervals. ${ }^{11}$ A minimum of 8 mice were used for each inoculum. Footpad harvests were done at the end of 12 months.

\section{Summary of results}

BACTERIAL LOAD USING DIFFERENT STAINING TECHNIQUES

\section{Multibacillary cases (MB): (Table 1)}

Of the $18 \mathrm{MB}$ cases studied, 6 scored negative in all the smears and the remaining 12 cases $(66 \cdot 6 \%)$ (Table 3 ) were positive with bacterial indices ranging from $1+$ to $5+$ in the skin.

On paraffin sections stained with TRIFF, 4 of the skin biopsies scored negative for acid-fast bacilli (AFB), whereas 1 skin biopsy showed negative anti-BCG staining. In the case of nerve biopsies, 8 out of 17 did not show AFB in TRIFF stained longitudinal and transverse (LS \& TS) sections, whereas all the nerves (both LS \& TS) were positive for anti-BCG.

In spite of the small sample size used for electron microscopy, all the nerve biopsies showed the presence of osmiophilic bacilli in the endoneurium (Tables 1 and 3).

\section{Paucibacillary cases (PB): (Table 2)}

None of the treated PB cases (BT-TT) showed any bacilli in the smear, whereas 2 of the skin biopsies stained with TRIFF showed a few bacilli in the deep dermal nerves. However 9 of the skin biopsies $(56 \cdot 2 \%)$ showed significant BCG positivity in the epithelioid cells.

Of the nerve biopsies, 2 showed bacilli in TRIFF, whereas 10 out of 16 nerve biopsies (62.5\% Table 3 ) showed BCG positivity mainly in the Schwann cells. It was interesting to note that 5 of the nerve biopsies showed the presence of osmiophilic bacilli mostly in Schwann cells at the ultrastructural level.

Table 3. Percentage of skin and nerve tissues of MB and PB cases showing bacterial positivity after full MDT

\begin{tabular}{|c|c|c|c|c|c|c|c|}
\hline & \multicolumn{3}{|c|}{ Skin } & \multicolumn{3}{|c|}{ Nerve } & \multirow[b]{2}{*}{$\begin{array}{c}\text { Total No. } \\
\text { of cases }\end{array}$} \\
\hline & $\begin{array}{c}\text { Smear } \\
(\%)\end{array}$ & $\begin{array}{c}\text { Histo } \\
(\%)\end{array}$ & $\begin{array}{c}\text { BCG } \\
(\%)\end{array}$ & $\begin{array}{l}\text { Histo } \\
(\%)\end{array}$ & $\begin{array}{c}\mathrm{BCG} \\
(\%)\end{array}$ & $\begin{array}{l}\text { EM } \\
(\%)\end{array}$ & \\
\hline BL-LL $\mathrm{c}>2$ years of MDT & $66 \cdot 6$ & $77 \cdot 7$ & $94 \cdot 4$ & $56 \cdot 9$ & 100 & 100 & 18 \\
\hline BT-TT $\mathrm{c}>6$ month of MDT & 0 & $12 \cdot 5$ & $56 \cdot 2$ & $12 \cdot 5$ & $62 \cdot 5$ & $31 \cdot 2$ & 16 \\
\hline
\end{tabular}


Table 4. Number of skin and nerve homogenates showing $M$. leprae growth in the FP of T200 $\times 5 \mathrm{R}$ mice

\begin{tabular}{lcccc}
\hline & \multicolumn{3}{c}{ Fold increase } \\
\cline { 2 - 4 } & \multicolumn{1}{c}{$>10$} & $>5$ & $<1$ & Total \\
\hline Skin & $2 / 10(20)^{*}$ & $2 / 10(20)$ & $6 / 10(60)$ & 10 \\
Nerve & $3 / 10(30)$ & $5 / 10(50)$ & $2 / 10(20)$ & 10 \\
\hline
\end{tabular}

* Numbers in parentheses are percentages.

Table 5. $M$. leprae-fold increase in the FP of TR mice with skin and nerve homogenates

\begin{tabular}{lccccc}
\hline & \multicolumn{2}{c}{ Skin } & & \multicolumn{2}{c}{ Nerve } \\
\cline { 2 - 3 } \cline { 5 - 6 } $\begin{array}{l}\text { Fold } \\
\text { increase }\end{array}$ & $\begin{array}{c}\text { No. of } \\
\text { FP counts }\end{array}$ & $\%$ & & $\begin{array}{c}\text { NO. of } \\
\text { FP counts }\end{array}$ & $\%$ \\
\hline 10 & 4 & $6 \cdot 7$ & & 10 & $19 \cdot 2$ \\
5 & 5 & $8 \cdot 3$ & & $13 \cdot 5$ \\
2 & 15 & $25 \cdot 0$ & & 12 & $23 \cdot 1$ \\
1 & 30 & $50 \cdot 0$ & & 14 & $26 \cdot 9$ \\
0 (no growth) & 6 & $10 \cdot 0$ & & 9 & $17 \cdot 3$ \\
\multicolumn{1}{c}{ Total } & 60 & & & 52 & \\
\hline
\end{tabular}

\section{BACTERIAL VIABILITY USING T $200 \times 5$ MICE}

Both skin and nerve homogenates of 2 patients and only nerve homogenate of 1 patient showed over 10-fold growth in the mouse footpad (Table 4).

One of the patients, where both skin and nerve homogenates showed $>10$ fold growth had completed 32 doses of MDT and he was on treatment during biopsy. The bacterial index of his smears ranged from $2+$ to $4+$. The other 2 patients had completed 24 doses of MDT, were smear negative and were off treatment for 2 months before biopsy.

In 5 out of 10 nerve homogenates $(50 \%)$ and 2 out of 10 skin homogenates $(20 \%)$ there was more than a 5 -fold increase in footpad count which requires reconfirming to satisfy the WHO protocol.

Even though the bacterial load per gram weight of skin tissue was higher than that of nerve tissue (Table 6) the number of footpads showing over a 10 -fold growth with nerve homogenate was twice more $(10 / 52$, i.e. $19 \cdot 2 \%)$ than that of the skin homogenate $(4 / 60$, i.e. $6 \cdot 7 \%$ ) suggesting the presence of a higher number of viable organisms in the nerve (Table 5). By applying the $\chi^{2}$ test for goodness of fit the difference was found to be of borderline significance of $p<0 \cdot 05$. 
Table 6. AFB count per gramme weight of the tissue

\begin{tabular}{|c|c|c|}
\hline No. & $\begin{array}{c}\text { Skin } \\
\begin{array}{c}\text { AFB count/gramme weight } \\
\text { of tissue }\end{array}\end{array}$ & $\begin{array}{c}\text { Nerve } \\
\text { AFB count/gramme weight } \\
\text { of tissue }\end{array}$ \\
\hline 1 & $6.2 \times 10^{7}$ & $2.21 \times 10^{7}$ \\
\hline 2 & $3.6 \times 10^{7}$ & $0.16 \times 10^{7}$ \\
\hline 3 & $50.4 \times 10^{7}$ & $13.2 \times 10^{7}$ \\
\hline 4 & $3.8 \times 10^{7}$ & $10.8 \times 10^{7}$ \\
\hline 5 & $25 \cdot 25 \times 10^{7}$ & $3.45 \times 10^{7}$ \\
\hline 6 & $33.65 \times 10^{7}$ & $1.344 \times 10^{7}$ \\
\hline 7 & $4.004 \times 10^{7}$ & $3.904 \times 10^{7}$ \\
\hline 8 & $22.36 \times 10^{7}$ & $<1 \times 10^{4}$ \\
\hline 9 & $16.85 \times 10^{7}$ & $1.130 \times 10^{7}$ \\
\hline 10 & $0.286 \times 10^{7}$ & $0.709 \times 10^{7}$ \\
\hline
\end{tabular}

\section{Discussion}

A semiquantitative analysis of the results reveal that detection of the BCG cross-reactive antigen using the PAP technique is far superior and more sensitive than the detection of acid-fast organisms using TRIFF staining in tissue sections, which in turn is superior to the smear technique. This is in accordance with the findings of Mshana et al. ${ }^{12}$ Interestingly, detection of osmiophilic bacilli using an osmium-fixed araldite embedded ultrathin section is similar to the BCG cross-reactive antigen detection system in spite of the small sample size.

It is noteworthy that among the paucibacillary cases there is no concordance between BCG positivity of skin and nerve biopsies even though both biopsies were obtained simultaneously from the most active site of involvement.

The continued presence of both integral and BCG cross-reactive antigen of $M$. leprae in skin and nerve biopsies of $\mathrm{MB}$ cases after completion of treatment is not surprising since it is expected that the dead bacteria and its residues may take longer to clear from intracellular locations. However, $56 \%$ of skin and $62 \%$ of nerve biopsies of PB cases showed a persistence of bacterial antigen which is surprising. It is assumed that the initial load of bacteria in these cases is not more than $10^{6}$. This low load combined with 2 highly potent bactericidal drugs taken for a period of $7-18$ months in some cases (Table 2) clearly raises questions regarding the ability of these individuals to mount a better immune response that facilitates faster bacterial clearance. It is worth mentioning that 4 of the patients (Nos 4, 7, 9 and 13, Table 2) who were showing a significant amount of antigen in both skin and nerve had not only taken 7-18 months of treatment but the biopsies under study were obtained 6-11 months af ter stopping the treatment. This is in contrast to the expectations that the clearance of bacterial products would be faster after the withdrawal of antileprosy drugs which are partially immunosuppressive. ${ }^{13,14}$ Alternative strategies need to be worked out to neutralize these antigens.

The presence of these antigens in any form of leprosy (PB or $\mathrm{MB}$ ) can pose a potential danger in bringing about reversal reactions. The study of how and where these antigens are located in relation to the activity of the lesion might have an important bearing on any impending reaction, and this is also being studied and will be reported elsewhere. 
Preliminary data in the second part of the study reveal that 2 out of 10 skin biopsies and 3 out of 10 nerve biopsies harboured significant numbers of viable bacteria, which is unexpectedly high. Our results also reveal that the viable number of bacteria in the nerve is twice that in the skin tissue. This observation calls for a fresh look at the efficacy of MDT which is the major tool in leprosy eradication programmes. We are inclined to believe that for cessation of therapy, the clinical evidence of disease inactivity and slit-skin smear negativity should be viewed with caution. Indeed a larger investigation including $\mathrm{MB}$ as well as PB cases needs to be undertaken, keeping in mind the possibility of multidrug resistance and bioavailability of antileprosy drugs.

\section{Acknowledgments}

We thank Dr R Ganapati, Director of BLP, Bombay, for the clinical materials, Dr Satish Arolkar (FMR) for doing the biopsies, Dr Geeta Samant (FMR) for doing patients' EMG, and Mr A Venugopalan (FMR) for the typing. We gratefully acknowledge the financial support of Lepra.

\section{References}

1 Antia NH. Leprosy-A disease of the Schwann cell. Ind J Lepr, 1982; 54: 599-604.

2 Srinivasan H, Rao KS, Iyer CGS. Discrepancy in the histopathological features of leprosy lesions in the skin and peripheral nerve-report of a preliminary study. Ind J Le pr, 1982; 54: 275-82.

${ }^{3}$ Shet ty VP, Antia NH, Jacobs JM. The pathology of early leprous neuropathy. J Neur Sci, 1988; 88: 115-31.

4 Ridley DS, Ridley MJ. Classification of nerves is modified by the delayed recognition of Mycobacterium leprae. Int J Lepr, 1986; 54: 596-606.

5 Antia NH, Pandya NJ. Qualitative histology and quantitative bacteriology in various tissues of 50 leprosy patients. Lepr Rev, 1976; 47: 175-83.

6 Subcommittee on clinical trials of the chemotherapy of leprosy (THELEP) scientific working group of the UNDP/World Bank/WHO special programme for Research and Training in Tropical Diseases. Persisting Mycobacterium leprae among THELEP trial patients in Bamaka and Chingleput. Lepr Rev, 1987; 58: 325-37.

7 Ridley DS. Classification of leprosy according to immunity-a five group system. Int J Lepr, 1966; 34: 25573.

8 WHO Study Group. Chemotherapy of leprosy for control programme. Technical Report series 1982; No. 675: 1-33.

9 Ridley DS. Bacterial indices in leprosy in theory and practice. Cochrane RG, Davey TF (eds) Bristol, John Wright \& Sons Ltd. 1964; 620-22.

10 Ridley DS. Skin biopsy in leprosy. 2nd ed. Bale 1988; Ciba Geigy.

11 Colston, MJ. Application of thymectomised irradiated mouse to the detection of persisting Mycobacterium leprae. Int J Lepr, 1982; 50: 83-9.

12 Mshana RN, Belehu A, Stoner GL, Haregewoin A, Harboe M. Demonstration of mycobacterial antigens in leprosy tissues. Int J Lepr, 1982; 50: 1-10.

13 Anderson R. Enhancement by clofazimine and inhibition by dapsone of production of prostaglandin E2 by human polymorphonuclear leukocytes in vitro. Antimicrob Agents Chemother, 1985; 27: 257.

14 Ganapati R, Revankar CR, Rashmi R Pai. Three years assessment of multidrug therapy in multibacillary leprosy cases. Ind J Lepr, 1987; 59: 44-9. 


\title{
Comparaison de la persistance de Mycobacterium leprae dans les nerfs périphéri- ques et dans la peau de patients sous traitement multidrogue
}

\author{
V P Shetty, K Suchitra, M W Uplekar et N H Antia
}

Résumé A l'aide de diverses techniques de coloration, nous avons déterminé le taux de contamination bactérienne de biopsies de la peau et des nerfs obtenues chez 18 cas de lèpre multibacillaires (MB) et 16 cas de lèpre paucibacillaires (PB). De plus, nous avons recherché le Mycobacterium leprae 'persisteur' dans des homogénats de peau et de nerf de 10 cas MB en utilisant la souris immuno-déprimée.

Des quantités significatives d'antigène des bacilles intégraux et du BCG en réaction croisée ont été décelées dans les tissus épidermiques et nerveux chez tous les cas MB (100\%); par contre, $56 \%$ des biopsies de peau et $62 \%$ des biopsies de nerf des cas PB ont montré la présence d'antigène du BCG en réaction croisée.

La détection de Mycobacterium leprae 'persisteur' dans 2/10 biopsies de peau (20\%) et 3/10 biopsies du nerf $(30 \%)$ chez les cas MB semble plus élevée que prévu après 2 années de traitement multidrogue.

\section{La persistencia del Mycobacterium leprae en el nervio perif erico comparada a la piel de los leprosos tratados con multi-drogas}

\author{
V P Shetty, K Suchitra, M W Uplekar y N H Antia
}

Resumen Biopsias de la piel y de nervios obtenidas de 18 leprosos multibacilares (MB) y 16 paucibacilares (PB) que habían recibido un tratamiento completo con el régimen de la OMS, fueron evaluadas para carga bacteriana utilizando diferentes técnicas de coloración. Además, productos homogenizados de piel y nervios en 10 casos MB fueron probados para Mycobacterium leprae 'persistor' mediante ratones immunosuprimidos.

Aunque se detectaron cantidades significativas de bacilos integros y antígeno BCG de reactividad cruzada de $M$. leprae tanto en tejidos de piel como de nervios, en todos los casos MB (100\%), $56 \%$ de las biopsias de piel y $62 \%$ de las de nervios en los casos PB tam bién mostraron la presencia de antígeno BCG de reactividad cruzada.

Se cree que la detección de $M$. leprae 'persistor' en 2/10 de las biopsias de la piel (20\%) y en 3/10 biopsias de nervios $(30 \%)$ en los casos MB fue inesperadamente alta después de 2 años de MDT. 